\title{
GROWTH AND NODULATION OF SOYBEAN PLANTS FERTILIZED WITH POULTRY LITTER
}

\author{
Desenvolvimento e nodulação de plantas de soja adubadas com cama de aves
}

\author{
Vilmar Antonio Ragagnin'1, Darly Geraldo de Sena Júnior², \\ Danyllo Santos Dias², Weslley Fernandes Braga 2 , Phelipe Diego Moraes Nogueira ${ }^{2}$
}

\begin{abstract}
Nowadays much of the chemical fertilizers used in Brazil come from imports, what creates the necessity to seek for alternative fertilizers. One possibility is organic fertilizers, including poultry litter, which presents increasing availability in various regions of the country, due to the expansion of the poultry industry. Despite its availability, there are no enough studies that show the benefits of using poultry litter on soybeans in substitution of mineral fertilizer. The present study aimed to evaluate the effect of different doses of poultry litter on leaf chlorophyll content, nodulation, and development of soybean plants. It was used a completely randomized design with five doses of poultry litter $\left(0,1,2,4\right.$ and $\left.8 \mathrm{tha}^{-1}\right)$ and a control with mineral fertilizer with four repetitions. On stages R1 and R5, chlorophyll readings were done using a portable meter and also the measurement of plant height. Plants were cut near the surface, roots were washed and the nodules were detached and counted. After that, it was determined the dry weight of plant roots, nodules, and shoots. Soybean fertilization with poultry litter increases the chlorophyll content of leaves, plant height, shoot dry matter, root dry matter, and nodulation. The use of poultry litter on soybean favors its growth with decreasing increments, except for root dry matter, and with an optimum dose for each variable. The supply of poultry litter can replace mineral fertilizers in terms of soybean growth.
\end{abstract}

Index terms: Organic fertilizer, Glycine max, chlorophyll.

\section{RESUMO}

Atualmente, boa parte dos fertilizantes utilizados no Brasil é importada, o que cria a necessidade de busca por fertilizantes alternativos. Uma possibilidade são os fertilizantes orgânicos, incluindo a cama de aves, que apresenta crescente disponibilidade em várias regiões do país, em razão da expansão da indústria avícola. Apesar da disponibilidade e potencial, não há estudos suficientes que mostrem os benefícios do uso da cama de aves na cultura da soja em substituição ao fertilizante mineral. No presente trabalho, objetivou-se avaliar o efeito de diferentes doses de cama de aves no teor de clorofila nas folhas, nodulação e desenvolvimento de plantas de soja cultivadas em casa de vegetação. Foi utilizado um delineamento inteiramente casualizado com cinco doses de cama de aves $\left(0,1,2,4\right.$ e $\left.8 \mathrm{t} \mathrm{ha}^{-1}\right)$ e testemunha com fertilizante mineral com quatro repetições. Nos estágios R1 e R5, leituras do teor de clorofila foram realizadas com um medidor portátil bem como a medição de altura de plantas. As plantas então foram cortadas rente ao solo, as raízes lavadas e os nódulos destacados e contados. Em seguida, foi determinada a matéria seca de raízes, nódulos e da parte aérea das plantas. A adubação com cama de aves aumenta o teor de clorofila foliar, altura de plantas, matéria seca da parte aérea, matéria seca de raízes e nodulação. Autilização de cama de aves na cultura da soja favorece seu desenvolvimento com incrementos decrescentes, com uma dose ótima para cada variável. O fornecimento de cama de aves pode substituir a adubação mineral em termos de desenvolvimento da cultura da soja.

Termos para indexação: Fertilizantes orgânicos, Glycine max, clorofila.

(Received in october 10, 2012 and approved in december 12, 2012)

\section{INTRODUCTION}

Soybean (Glycine Max), family Fabaceae, stands out as the main crop in the Brazilian market, occupying approximately 25 million hectares and accounting for about $50 \%$ of the cultivated area in the country (COMPANHIA NACIONALDE ABASTECIMENTO-CONAB, 2012).

One of the main factors that limits Brazilian agricultural productivity is the high cost of inputs, of which the fertilizer is more expensive (MENEGATTI; BARROS,
2007). Furthermore, much of the chemical fertilizers used in Brazil come from imports, which makes it necessary to look for alternative fertilizers to ensure the sustainability of the activity. One possibility is organic fertilizers, including the poultry litter, which has been outstanding due to the increasing availability in various regions of the country. Brazilian poultry industry slaughtered of about 4.99 billion broilers in 2010. Only in the State of Goiás, there was an increase in poultry slaughtering under sanitary inspection

\footnotetext{
1Universidade Federal de Goiás - Campus Jataí - Rod BR 364 - km 192 - Cx. P. 03 - 75800-000 - Jataí - GO - Brasil - vilmar.ragagnin@gmail.com ${ }^{2}$ Universidade Federal de Goiás - Campus Jataí - Jataí - GO - Brasil
} 
of $498.55 \%$ from the year 2000 , reaching the number of about 301.3 million birds in 2010 (SECRETARIA DE ESTADO DE GESTÃO E PLANEJAMENTO-SEGPLAN, 2011).

The poultry litter is a mixture of the substrate, usually wood chips or rice straw, with bird droppings, feathers, and leftover food. Its composition can vary with the quantity and quality of substrate used. Generally, presents contents around 24 to $40 \mathrm{~g} \mathrm{~kg}^{-1} \mathrm{~N}, 20$ to $35 \mathrm{~g} \mathrm{~kg}^{-1}$ of $\mathrm{P}_{2} \mathrm{O}_{5}, 18$ to $35 \mathrm{~g} \mathrm{~kg}^{-1}$ of $\mathrm{K}_{2} \mathrm{O}$, and 65 to $90 \mathrm{~g} \mathrm{~kg}^{-1}$ of dry matter (KONZEN; ALVARENGA, 2000). Due to its composition and availability at low cost in the rural properties, this residue can be used by farmers in the fertilization of crops (MENEZES et al., 2004). The use of poultry litter as fertilizer became even more promising after legislation which prevents its use as cattle feed ingredient.

Some studies have demonstrated beneficial effects of using animal waste as yield increases in crops such as soybeans (CARVALHO et al., 2011) and corn (HANISCH; FONSECA; VOGT, 2011) by improving physical, chemical, and biological soil properties (ANDRADE et al. 2011). However, the amount of organic matter and nutrients, mainly nitrogen and phosphorus present in this material, could make it accountable for significant adverse environmental impacts if not properly treated or used. On the other hand, when properly handled, it can replace partially or totally the chemical fertilization (BLUM et al. 2003).

On soybeans, according to Behling et al. (2009), a high supply of soil $\mathrm{N}$ to plants can lead to high absorption rates of this nutrient, possibly resulting in a reduction of nitrogen fixation. Despite the availability and potential, there are no enough studies in soybeans showing the benefits of using poultry litter in substitution of mineral fertilizer.

The present greenhouse study aimed to evaluate the effect of different doses of poultry litter on leaf chlorophyll content, nodulation, and development of soybean plants

\section{MATERIAL AND METHODS}

The work was conducted in the city of Jataí, located in the micro-region of Southwest Goiás (17 53 ' S; 52 $43^{\prime}$ W and altitude of approximately 700m), in the 2009/2010 season. It was used soil from a cultivated area classified as Latossolo Vermelho Distroférrico (Brazilian Soil Classification System) with 291, 354 and $355 \mathrm{~g} \mathrm{~kg}^{-1}$ of sand, silt, and clay, respectively, which was $2 \mathrm{~mm}$-sieved and placed in $4 \mathrm{dm}^{3}$ pots. Results of soil chemical analysis of the 0-0,2 $\mathrm{m}$ soil layer are shown in table 1 . The sowing of soybean, variety Msoy 7211RR, was held in November 2009, with six seeds per pot. After emergence, were kept four plants per pot. The seeds were inoculated with a commercial inoculant with $5 \times 10^{9}$ colony forming units per gram at a dose of $50 \mathrm{~g} \mathrm{~kg}^{-1}$ of seeds.

It was used a completely randomized design with five doses of poultry litter $\left(0,1,2,4\right.$ and $\left.8 \mathrm{tha}^{-1}\right)$ and a control fertilized with $100 \mathrm{~kg} \mathrm{P}_{2} \mathrm{O}_{5} \mathrm{ha}^{-1}$ and $70 \mathrm{~kg} \mathrm{~K}_{2} \mathrm{O} \mathrm{ha}^{-1}$ with four repetitions. The contents of $\mathrm{N}, \mathrm{P}_{2} \mathrm{O}_{5}$ and $\mathrm{K}_{2} \mathrm{O}$ of the poultry litter were 28,30 , and $34 \mathrm{~g} \mathrm{~kg}^{-1}$, respectively.

In the $\mathrm{R} 1$ stage, the first reading with a portable chlorophyll meter (clorofiLOG CFL 1030) was carried out and the height of plants was measured, the last considered as the distance from the ground to the end of the main stem. In stage R5, the chlorophyll reading and measurement of plant height were repeated and then the plants were cut close to the surface. The soil was removed from the pot and placed on a $2 \mathrm{~mm}$ mesh sieve, roots were washed and the nodules were detached and counted. All the material was dried in a ventilated oven at $60^{\circ} \mathrm{C}$ for determination of dry matter of roots, nodules, and shoots of plants.

Data were submitted to analysis of variance and when significance was found, means were compared by Dunnett test at $5 \%$ probability, using the software package Genes (CRUZ, 2001). The effects of doses of poultry litter were evaluated through regression analysis, the models being chosen based on coefficient of determination values and adequacy of the biological model, using the software package ESTAT (BARBOSA et al., 1992).

\section{RESULTS AND DISCUSSION}

Based on the values obtained in the experiment there was a significant difference for the factor doses of poultry litter for the variables chlorophyll readings in R5 stage and plant height. To the variable chlorophyll readings in R1 stage, significant effect was not observed (Table 2).

Table 1 - Chemical analysis and organic matter $(\mathrm{OM})$ content of the experimental area, 0-20 cm layer.

\begin{tabular}{|c|c|c|c|c|c|c|c|c|c|c|}
\hline $\mathrm{pH}$ & $\mathrm{K}$ & $\mathrm{P}$ & $\mathrm{Ca}$ & $\mathrm{Mg}$ & $\mathrm{Al}$ & $\mathrm{H}+\mathrm{Al}$ & CTC & SB & V & MO \\
\hline $\mathrm{H}_{2} \mathrm{O}$ & -----mg dm ${ }^{-3}$ & & $\begin{array}{ll}---- \\
--1\end{array}$ & $-\cdots$ & $\mathrm{cmol}_{\mathrm{c}}$ & & $\ldots$ & & $--\%--$ & $-\mathrm{g} \mathrm{kg}^{-1}-$ \\
\hline 5.73 & 50.02 & 0.80 & 1.26 & 0.89 & 0.06 & 5.97 & 8.25 & 2.28 & 27.61 & 31.16 \\
\hline
\end{tabular}

Ciênc. agrotec., Lavras, v. 37, n. 1, p. 17-24, jan./fev., 2013 
Working with mineral $\mathrm{N}$ in soybeans, Nogueira, Sena and Ragagnin (2010) evidenced significant differences in leaf chlorophyll concentration in R1 and R5 stage under increasing nitrogen levels. However, in this work the chlorophyll readings at the R1 stage were not significant. This result suggests that the range of poultry litter doses used did not increase the soil nitrogen content in the initial stage of plant development. It is probably related to the decomposition rate of the residue, since the nitrogen in the poultry litter is not readily available to the crop (COMISSÃO DE FERTILIDADE DO SOLO DE ESTADO DE MINAS GERAIS-CFSEMG, 1989).

The treatments and the poultry litter were found significant for the four variables, dry matter of shoots, roots, nodules as well as mean number of nodules (Table 3).

The contrast treatment $\mathrm{x}$ control with mineral fertilizer was found significant only for nodules dry matter. Lobo et al. (2012) found great number and mass of nodules using organic residue in soybeans and attributed these results to the numerous nutrients present in the sewage sludge, which can increase the activity of soil microorganisms, including rhizobia.

The use of poultry litter compared to control with chemical fertilizer, by Dunnett test, show that certain doses of poultry litter did not differ from mineral fertilizer for some of the variables evaluated (Table 4).

It was observed that the mineral fertilization showed higher responses for all variables when compared with the absence of fertilization. This shows the low nutrient availability in the soil used, being necessary the using of fertilizer, organic or mineral, for the soybean crop. Evaluating each variable separately, it was observed that for chlorophyll readings of the R5 stage, 4 and $8 \mathrm{tha}^{-1}$ poultry litter did not differ from chemical fertilization. However, the doses 1 and 2 t ha ${ }^{-1}$ have higher values compared to the control. This result indicates that the poultry litter provides nitrogen, favoring the accumulation of chlorophyll, but at higher doses the effect is not as pronounced.

For the plant height at R1 stage, the doses of poultry litter did not differ from the mineral fertilizer. But at the R5 stage, the plant height was significantly different

Table 2 - Summary of analysis of variance for chlorophyll readings in R1 stage (CHLR1), chlorophyll readings in R5 stage (CHLR5), plant height on R1 stage (PLHR1), and plant height on R5 stage (PLHR5) as a function of doses of poultry litter and control treatment with mineral fertilizer on soybeans.

\begin{tabular}{|c|c|c|c|c|c|c|c|c|c|}
\hline \multirow{2}{*}{ Sources of Variation } & \multirow{2}{*}{$\mathrm{DF}$} & \multicolumn{2}{|c|}{ CHLR1 } & \multicolumn{2}{|c|}{ CHLR5 } & \multicolumn{2}{|c|}{ PLHR1 } & \multicolumn{2}{|c|}{ PLHR5 } \\
\hline & & MS & $\mathrm{F}$ & MS & $\mathrm{F}$ & MS & $\mathrm{F}$ & MS & $\mathrm{F}$ \\
\hline Treatments & 5 & 14.00 & $0.66^{\mathrm{ns}}$ & 38.42 & $11.31 * *$ & 43.50 & $13.62 * *$ & 471.64 & $9.19 * *$ \\
\hline Poultry Litter & 4 & 3.48 & $0.16^{\mathrm{ns}}$ & 46.23 & $13.61 * *$ & 49.98 & $15.65 * *$ & 574.96 & $11.20 * *$ \\
\hline Treat x Control. & 1 & 56.10 & $2.64^{\mathrm{ns}}$ & 7.19 & $2.12^{\mathrm{ns}}$ & 17.61 & $5.51^{*}$ & 58.32 & $1.14^{\mathrm{ns}}$ \\
\hline Error & 18 & 21.20 & & 3.40 & & 3.19 & & 51.33 & \\
\hline $\mathrm{CV} \%$ & & 12.69 & & 4.42 & & 8.12 & & 10.98 & \\
\hline
\end{tabular}

ns, ** not significant and significant at $1 \%$ probability by the $\mathrm{F}$ test, respectively.

Table 3 - Summary of analysis of variance for shoot dry matter (SDM), root dry matter (RDM), nodules dry matter (NDM), and mean number of nodules per plant (NNP) as a function of doses of poultry litter and control treatment with mineral fertilizer on soybeans.

\begin{tabular}{lcrrrrrrrr}
\hline \multirow{2}{*}{$\begin{array}{c}\text { Sources of } \\
\text { Variation }\end{array}$} & \multirow{2}{*}{ DF } & \multicolumn{2}{c}{ SDM } & \multicolumn{2}{c}{ RDM } & \multicolumn{2}{c}{ NDM } & \multicolumn{2}{c}{ NNP } \\
\cline { 2 - 10 }$y$ & & \multicolumn{1}{c}{ MS } & F & MS & F & MS & F & MS & F \\
\hline Treatments & 5 & 667.45 & $33.34^{* *}$ & 218.61 & $5.46^{* *}$ & 8.48 & $55.54^{* *}$ & 9796.46 & $27.51^{* *}$ \\
P. Litter & 4 & 834.30 & $41.68^{* *}$ & 271.61 & $6.78^{* *}$ & 9.56 & $62.67^{* *}$ & 11900.89 & $33.42^{* *}$ \\
Tr. x Ctr. & 1 & 0.04 & $0.002^{\mathrm{ns}}$ & 6.58 & $0.16^{\mathrm{ns}}$ & 4.12 & $27.03^{* *}$ & 1378.71 & $3.87^{\mathrm{ns}}$ \\
\hline Error & 18 & 20.02 & & 40.04 & & 0.15 & & 356.05 & \\
\hline CV\% & & 9.54 & & 19.69 & & 12.83 & & 17.38 \\
\hline
\end{tabular}

\footnotetext{
** significant at $1 \%$ probability by $\mathrm{F}$ Test.
} 
compared to mineral fertilizer at all doses used. Doses 2, 4, and $8 \mathrm{tha}^{-1}$ were higher than chemical fertilizer while the dose of $1 \mathrm{t} \mathrm{ha}^{-1}$ was lower. This shows that at doses lower than $2 \mathrm{t} \mathrm{ha}^{-1}$ the amount of nutrients provided by the poultry litter may not be sufficient to a satisfactory growth compared to mineral fertilizers.

Regarding dry matter, it was observed that at doses of 4 and $8 \mathrm{tha}^{-1}$, a greater dry matter accumulation occurred, both in shoots and roots. For its part, the doses of 1 and $2 \mathrm{t}$ ha $^{-1}$, did not differ in terms of shoot dry matter, but differed for roots dry matter when compared with mineral fertilization.

Plants that showed higher values of number of nodules in relation to mineral fertilization were those that received doses of $4 \mathrm{tha}^{-1}$. However, nodule dry matter of plants that received $4 \mathrm{t} \mathrm{ha}^{-1}$ did not differ from mineral fertilization, indicating that despite having a greater amount of nodules its mass did not differ from mineral fertilizer. Pavanelli and Araújo (2009) noticed low nodulation of soybean plants in certain soils and attributed that to low fertility levels. In a work with sewage sludge in soybeans, Lobo et al. (2012) observed an increase in number and dry matter of nodules due to the increase of the sludge doses up to $20 \mathrm{t} \mathrm{ha}^{-1}$ and after this there was a decrease.

To evaluate the effect of doses of poultry litter on the studied variables, further polynomial regression was performed, with the model chosen as a better biological adequacy to the effects. The response for all variables occurred with quadratic behavior, except for root dry matter, where the crop responded linearly.

According to the fitted equation for chlorophyll readings in stage $\mathrm{R} 5$ (CHLR5), the dose that would provide greater chlorophyll reading would be $4.3 \mathrm{t} \mathrm{ha}^{-1}$. Also, according to the equation, the use of a dose of $0.6 \mathrm{t} \mathrm{ha}^{-1}$ of poultry litter would provide a numeric value of chlorophyll reading similar to that observed with mineral fertilizer (Figure 1).

Table 4 - Means of the variables chlorophyll readings in R5 stage (CHLR5), plant height on R1 stage (PLHR1), plant height on R5 stage (PLHR5), shoot dry matter (SDM), root dry matter (RDM), nodules dry matter (NDM), and mean number of nodules per plant (NNP) as a function of doses of poultry litter and control treatment with mineral fertilizer (Mineral) on soybeans.

\begin{tabular}{cccccccc}
\hline Doses & CHLR5 & PLHR1 & PLHR5 & SDM & RDM & NDM & NNP \\
\hline 0 & 36.40 & 15.83 & 44.67 & 22.87 & 21.06 & 0.36 & 17.56 \\
1 & 44.32 & $21.38^{\mathrm{ns}}$ & 61.83 & $45.42^{\mathrm{ns}}$ & 32.60 & 2.63 & $97.75^{\mathrm{ns}}$ \\
2 & 44.24 & $22.29^{\mathrm{ns}}$ & 72.83 & $50.86^{\mathrm{ns}}$ & 28.48 & 3.06 & $117.38^{\mathrm{ns}}$ \\
4 & $43.80^{\mathrm{ns}}$ & $23.38^{\mathrm{ns}}$ & 71.75 & 56.14 & 36.99 & $4^{\mathrm{ns}}$ & 163.81 \\
8 & $40.88^{\mathrm{ns}}$ & $25.21^{\mathrm{ns}}$ & 71.75 & 59.29 & 42.72 & $4^{\mathrm{ns}}$ & $129.31^{\mathrm{ns}}$ \\
\hline Mineral & 40.46 & 23.92 & 68.75 & 46.80 & 30.96 & 3.97 & 125.50 \\
\hline
\end{tabular}

Means followed by ${ }^{\text {ns }}$ on column do not differ from control (Mineral) by Dunnet test at $5 \%$ probability.

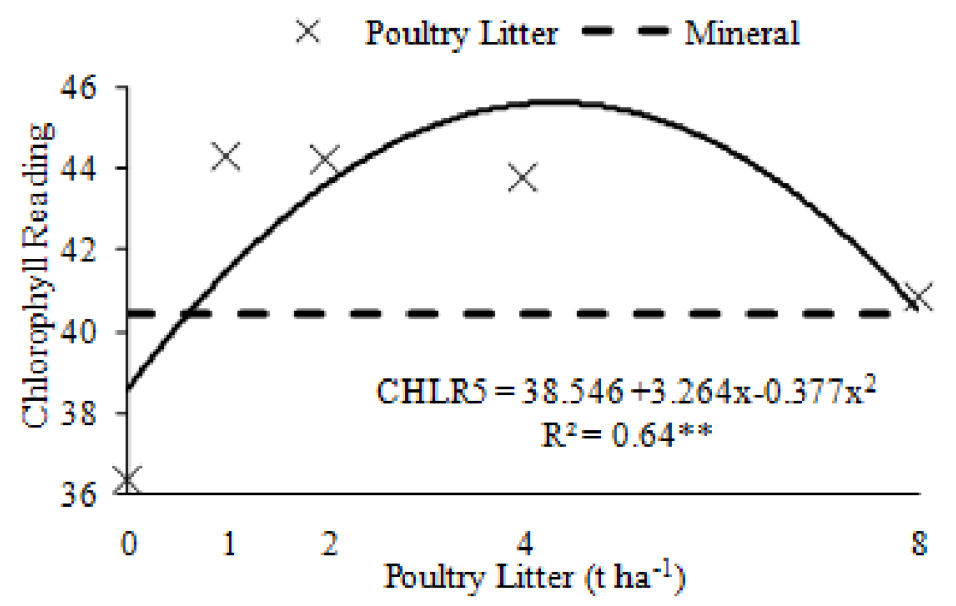

Figure 1 - Chlorophyll readings in stage R5 in response to doses of poultry litter 
On figure 2 are presented the equations for the variable plant height in stages R1 and R5. According to these, the doses of 3.4 and $2.1 \mathrm{t} \mathrm{ha}^{-1}$, respectively, would provide values similar to those observed with mineral fertilizer.

By the adjusted models, the greatest heights of plants were observed at doses $6.2 \mathrm{t} \mathrm{ha}^{-1}(\mathrm{R} 1)$ and $5.3 \mathrm{tha}^{-1}$ (R5). The need for a higher dose of poultry litter at the R1 stage in relation to the $\mathrm{R} 5$ stage for higher plant height is attributed to a partial availability of nutrients in the poultry litter. Progressive mineralization of organic residues by soil microorganisms gradually increases the nutrient availability. The quadratic effect, in turn, may be caused by nutritional imbalance in the soil solution, which, according to Rodrigues and Casali (1999), can be caused by high doses of organic fertilizers with possibility of soil salinization.

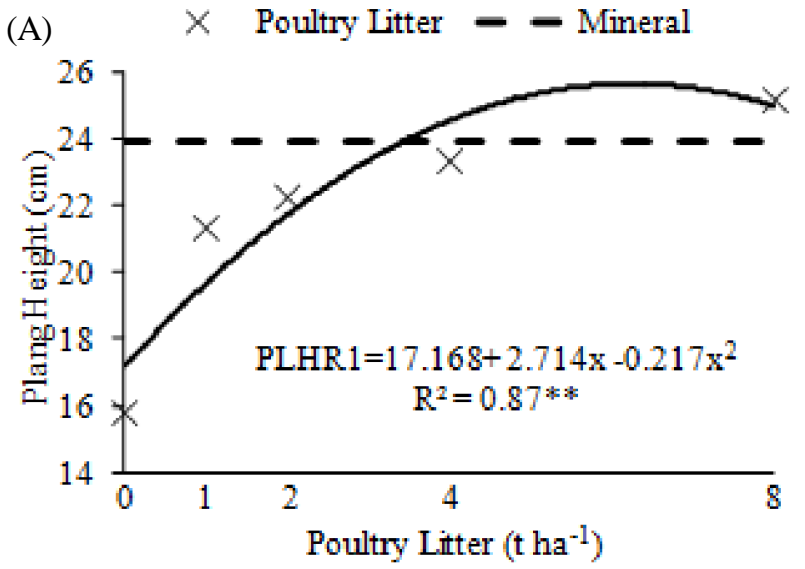

Comparing the use of optimal dose of poultry litter with mineral fertilizer for plant height, it is observed that the optimal dose would provide an increase of $12.7 \%$ and $7.2 \%$ in stages $\mathrm{R} 1$ and $\mathrm{R} 5$, respectively, reinforcing the benefits of organic in relation to mineral fertilization. Carvalho et al. (2011) obtained similar results in which the maximum height of soybean plants was associated with high doses of poultry litter and also noted that plant height was higher when mineral and organic fertilization were associated.

For the variables dry matter of shoots and roots the doses of poultry litter that would provide similar values to those observed in the mineral fertilizer were 1.8 and 2.4 $\mathrm{t} \mathrm{ha}^{-1}$, respectively (Figure 3 ).

According to the equation adjusted, the dose of maximum dry matter accumulation in shoots would be 5.7 $\mathrm{t} \mathrm{ha}{ }^{-1}$, whereas for the variable dry roots the response
(B)

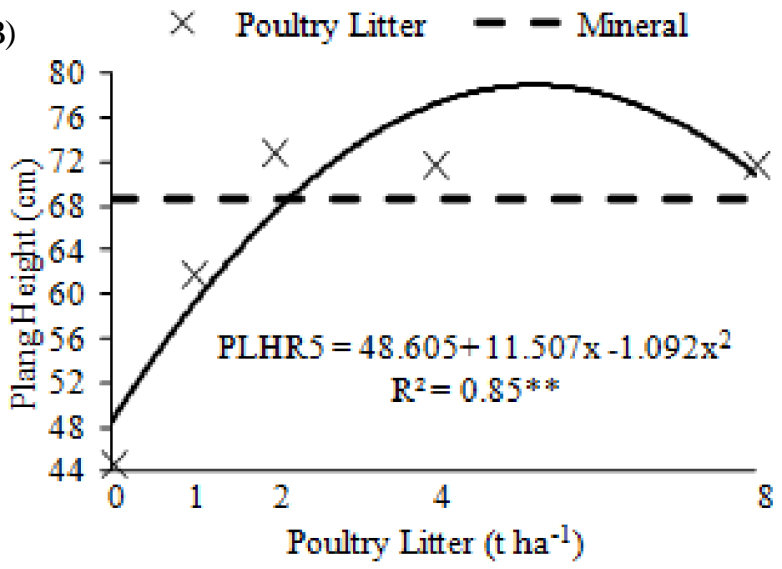

Figure 2 - Height of soybean plants at the R1 stage (A) and R5 stage (B) in response to doses of poultry litter.
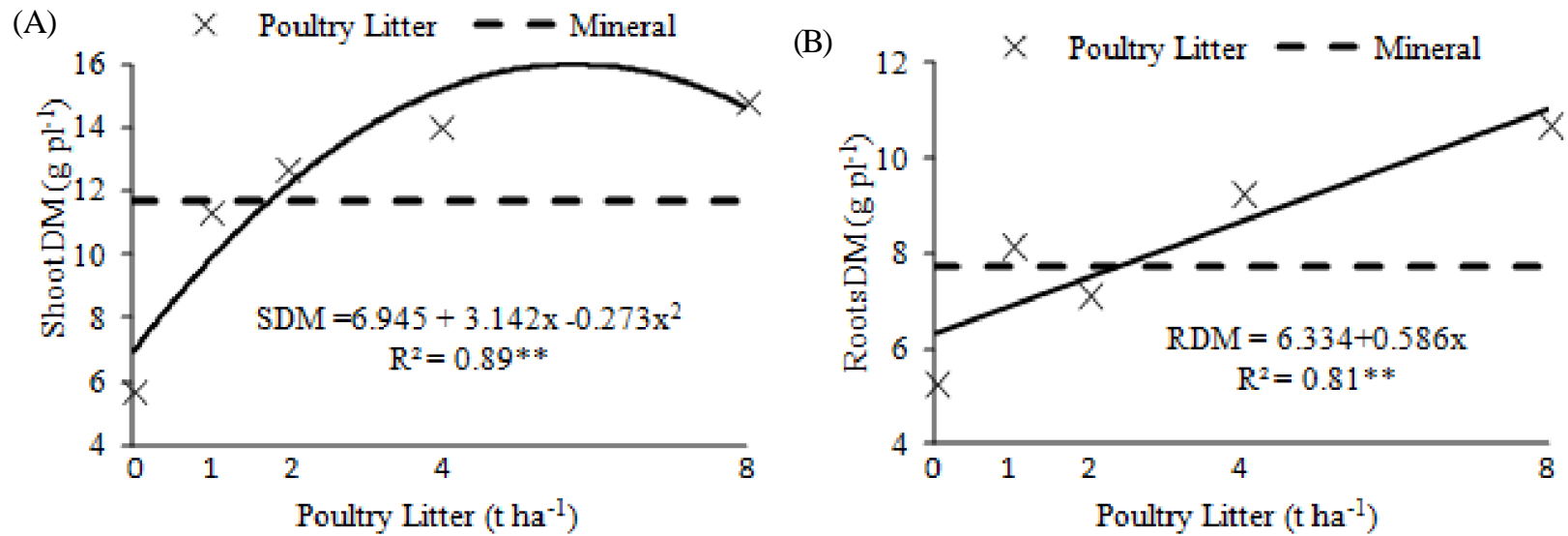

Figure 3 - Dry matter of shoots (A) and roots (B) on R5 stage in response to doses of poultry litter. 
was linear. Comparing the value that would be obtained with the optimal dose in relation to the mineral treatment, the optimal dose would accumulate $36.6 \%$ more dry matter on shoots.

The shoot response may have been influenced by the nutritional status of the crop, whereas the root response by physical soil properties. It is possible that addition of poultry litter resulted in soil physical characteristics that favored root development and has not been affected by nutritional imbalance in higher doses as happened with the crop shoots. There is a positive correlation between shoot dry matter at flowering and grain yield. Therefore, it is reasonable to assume that plants with more dry mass would be more productive (LOBO et al., 2012). Regarding the soil properties, Blum et al. (2003) found that the use of poultry litter promotes the addition of organic matter, improving related soil properties such as greater water retaining capacity, better aeration, increasing $\mathrm{pH}$, and reduction of exchangeable aluminum levels, creating a more suitable environment for the proper development of the microbial flora and root system. Nogueira et al. (2010), working with mineral N, found linear responses for both variables, but Lobo et al. (2012) found quadratic response to shoot dry matter with decrease after $26 \mathrm{t}$ $\mathrm{ha}^{-1}$ of sewage sludge.

The effect of poultry litter on plants nodulation is presented in Figure 4.

It is observed that the doses 3.2 and $2.1 \mathrm{t} \mathrm{ha}^{-1}$ would provide similar values to those observed with mineral fertilizers for dry matter of nodules and mean number of nodules per plant, respectively. The doses of poultry litter that would yield higher values of dry matter of nodules

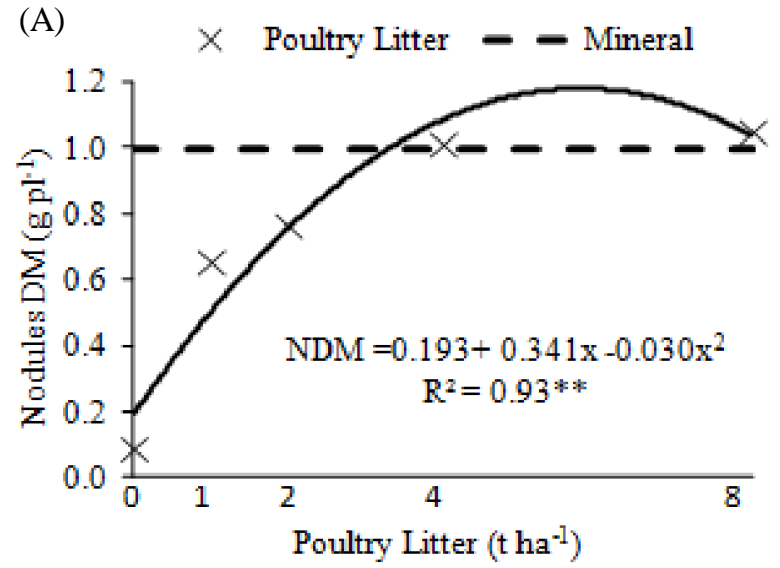

and mean number of nodules per plant were obtained with doses of 5.8 and $5.1 \mathrm{t} \mathrm{ha}^{-1}$, respectively.

It was expected that the nodulation would be affected by the increase in levels of poultry litter, since Mendes et al. (2008) found a reduction of nodulation in conventional and no tillage systems using $200 \mathrm{~kg}$ of mineral $\mathrm{N} \mathrm{ha}^{-1}$. Lobo et al. (2012) attributed the reduced number and mass of nodules in high doses of sewage sludge to its $\mathrm{N}$ content. In this work, with the optimum rates for nodule dry matter and mean number of nodules, it would have been applied 159.6 and $142.8 \mathrm{~kg} \mathrm{ha}^{-1}$, respectively, of mineral $\mathrm{N}$, according to the analysis of poultry litter. However, Empresa Brasileira de Pesquisa Agropecuária Embrapa (2010) suggests that until $20 \mathrm{~kg} \mathrm{~N} \mathrm{ha}^{-1}$ there is no damage to nodulation. Although, comparing the results observed in the zero dose of poultry litter to that obtained in the treatment with mineral fertilizer (Figure 4), it can be noted that the soil had low availability of nutrients, which may have limited nodulation in treatments with low dose of poultry litter.

Considering the levels of $\mathrm{N}, \mathrm{P}_{2} \mathrm{O}_{5}$, and $\mathrm{K}_{2} \mathrm{O}$ in the poultry litter, at a dose of $8 \mathrm{t} \mathrm{ha}^{-1}$, it was applied 224,240 , and $272 \mathrm{~kg} \mathrm{ha}^{-1}$, respectively. Of this total applied, only 50 percent (112 kg ha-1) of $\mathrm{N}$ and 60 percent (144 kg ha-1) of $\mathrm{P}_{2} \mathrm{O}_{5}$ would be available in the first year, whereas the $\mathrm{K}_{2} \mathrm{O}$ is not impacted by mineralization rate being totally available to crops in the first year of application (CFSEMG, 1989).

Brandelero, Peixoto and Ralisch et al. (2009) observed a significant correlation among soybean yield, nodulation, and dry matter of leaves. Thus, since the poultry litter favored nodulation, it is expected under field conditions a good correlation of doses of poultry litter with soybean yield.

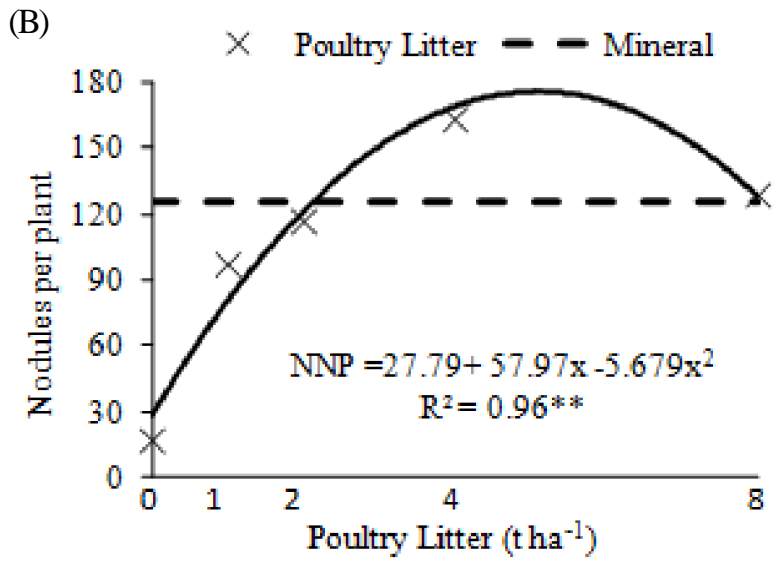

Figure 4 - Nodules dry matter (A) and mean number of nodules per plant (B) in response to doses of poultry litter.

Ciênc. agrotec., Lavras, v. 37, n. 1, p. 17-24, jan./fev., 2013 


\section{CONCLUSIONS}

Soybean fertilization with poultry litter in greenhouse conditions increases the chlorophyll content of leaves, plant height, shoot dry matter, root dry matter, and nodulation

The use of poultry litter on soybean favors its growth with decreasing increments, except for root dry matter, and with an optimum dose for each variable.

The supply of poultry litter can replace mineral fertilizers in terms of soybean growth.

\section{REFERENCES}

ANDRADE, A. R. S. et al. Desenvolvimento da cultura do sorgo em um Latossolo Amarelo submetido à adubação orgânica. Revista Brasileira de Tecnologia Aplicada nas Ciências Agrárias, Guarapuava, v.4, n.2, p.137-151, 2011.

BARBOSA, J. C.; MALHEIROS, E. B.; BANZATTO, D. A. ESTAT: um sistema de análises estatísticas de ensaios agronômicos. Versão 2.0. Jaboticabal: Unesp, 1992.

BEHLING, M. et al. Nodulação, acúmulo de nitrogênio no solo e na planta, e produtividade de soja em solo tratado com lodo de estação de tratamento de resíduos industriais. Bragantia, Campinas, v.68, p.453-462, 2009.

BLUM, L.E.B. et al. Produção de moranga e pepino em solo com incorporação de cama aviária e casca de pinus. Horticultura Brasileira, Brasília, v.21 n.4, p.627-631, 2003.

\section{BRANDELERO, E. M.; PEIXOTO, C. P.; RALISCH, R.}

Nodulação de cultivares de soja e seus efeitos no rendimento de grãos. Semina: Ciências Agrárias, Londrina, v.30 n.3, p.581-588, 2009.

CARVALHO, E. R. et al. Fertilizante mineral e resíduo orgânico sobre características agronômicas da soja e nutrientes no solo. Revista Ciência Agronômica, Fortaleza, v.42, n.4, p.930-939, 2011.

\section{COMISSÃO DE FERTILIDADE DO SOLO DE ESTADO DE MINAS GERAIS-CFSEMG. Recomendações para o uso de corretivos e fertilizantes em Minas Gerais. $4^{\text {a }}$ Aproximação, Lavras, 1989, 159p.}

COMPANHIANACIONAL DEABASTECIMENTOCONAB. Acompanhamento da safra brasileira: grãos: décimo primeiro levantamento, agosto/2012. Brasília, 2012. 29p. Disponível em: <http://www.conab.gov.br/ conteudos.php? $\mathrm{a}=1253 \& \mathrm{t}=2>$. Acesso em: 20 de agosto 2012.

CRUZ, C. D. Programa genes: versão Windows; aplicativo computacional em genética e estatística. Editora UFV, Viçosa, 2001, 648p.

EMPRESA BRASILEIRA DE PESQUISA AGROPECUÁRIA-EMBRAPA. Tecnologias de produção de soja - região central do Brasil 2009 e 2010. Londrina: Embrapa Soja/ Embrapa Cerrado/ Embrapa Agropecuária Oeste. 2010. 261p.

HANISCH, A. L.; FONSECA, J. A.; VOGT, G. A. Adubação do milho em um sistema de produção de base agroecológica: desempenho da cultura e fertilidade do solo. Revista Brasileira de Agroecologia, Cruz Alta, v.7, n.1, p.176-186, 2011.

KONZEN, E. A.; ALVARENGA, R. C. Fertilidade de Solos: Adubação Orgânica. Embrapa Milho e Sorgo, Sistemas de Produção, 1., 2000 Disponível em: <http:// ainfo.cnptia.embrapa.br/digital/bitstream/item/27333/1/ Fertilidade-de-solos-Adubacao.pdf $>$. Acesso em dezembro de 2012.4p.

LOBO, T. F. et al. Crescimento e fixação biológica do nitrogênio em soja cultivada com doses de lodo de esgoto compostado. Semina: Ciências Agrárias, Londrina, v.33, n.4, p.1333-1342, 2012.

MENDES, I. C. et al. Adubação nitrogenada suplementar tardia em soja cultivada em latossolos do Cerrado.

Pesquisa Agropecuária Brasileira, Brasília, v.43, p.10531060, 2008.

MENEGATTI, A. L. A.; BARROS, A. L. M. Análise comparativa dos custos de produção entre soja transgênica e convencional: um estudo de caso para o Estado do Mato Grosso do Sul. Revista de Economia e Sociologia Rural, Brasília, v.45, n. 1, p.163-183, 2007.

MENEZES, J. F. S. et al. Cama de frango na agricultura: perspectivas e viabilidade técnica e econômica. Boletim técnico, 3 Fesurv, Rio Verde, 2004, 28p. 
NOGUEIRA, P. D. M., SENAJUNIOR, D. G., RAGAGNIN, V. A. Clorofila foliar e nodulação em soja adubada com nitrogênio em cobertura, Global Science and

Technology, Rio Verde, v.3, p.117-124, 2010.

PAVANELLI, L. E., ARAÚJO, F. F. Fixação biológica de nitrogênio em soja em solos cultivados com pastagens e culturas anuais do oeste paulista. Bioscience Journal, Uberlândia, v.25, n.1, p.21-29, 2009
RODRIGUES, E. T.; CASALI, V. W. D. Rendimento e concentração de nutrientes em alface, em função das adubações orgânica e mineral. Horticultura Brasileira, Brasília, v.17 n.2, p.125-128, 1999.

SECRETARIADEESTADODEGESTÃOE PLANEJAMENTO-SEGPLAN. Goiás em Dados 2011

Superintendência de Estatísticas, Pesquisa e Informações Socioeconômicas - Goiânia: SEGPLAN 2011, 106 p. 